\title{
INL Wind Farm Project Description Document
}

Gary Seifert

July 2009

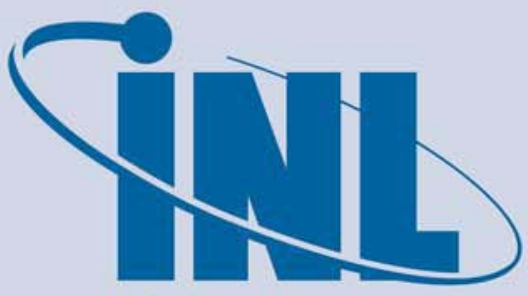

Idaho National Laboratory 
INL/EXT-09-16045

\title{
INL Wind Farm Project Description Document
}

\author{
Gary Seifert
}

July 2009

\author{
Idaho National Laboratory \\ Wind Powering America Project \\ Idaho Falls, Idaho 83415 \\ http://www.inl.gov
}

Prepared for the

U.S. Department of Energy

Assistant Secretary for Energy Efficiency and Renewable Energy

Under DOE Idaho Operations Office

Contract No. DE-AC07-05ID14517 


\section{DISCLAIMER}

This information was prepared as an account of work sponsored by an agency of the U.S. Government. Neither the U.S. Government nor any agency thereof, nor any of their employees, makes any warranty, expressed or implied, or assumes any legal liability or responsibility for the accuracy, completeness, or usefulness, of any information, apparatus, product, or process disclosed, or represents that its use would not infringe privately owned rights. References herein to any specific commercial product, process, or service by trade name, trade mark, manufacturer, or otherwise, does not necessarily constitute or imply its endorsement, recommendation, or favoring by the U.S. Government or any agency thereof. The views and opinions of authors expressed herein do not necessarily state or reflect those of the U.S. Government or any agency thereof. 
This page intentionally left blank. 


\section{ABSTRACT}

The INL wind farm project proposes to install a $20 \mathrm{MW}$ to $40 \mathrm{MW}$ wind farm on government property, consisting of approximately ten to twenty fullsized (80-meter hub height) towers with $2 \mathrm{MW}$ turbines, and access roads. This includes identifying the optimal turbine locations, building access roads, and pouring the tower foundations in preparation for turbine installation.

The project successfully identified a location on INL lands with commercially viable wind resources (i.e., greater than $13.5 \mathrm{mph}$ at 50 meters above ground level annual average wind speed) for a 20 to $40 \mathrm{MW}$ wind farm. Additionally, the proposed wind farm was evaluated against other General Plant Projects, General Purpose Capital Equipment projects, and Line Item Construction Projects at the INL to show the relative importance of the proposed wind farm project. 
This page intentionally left blank. 


\section{CONTENTS}

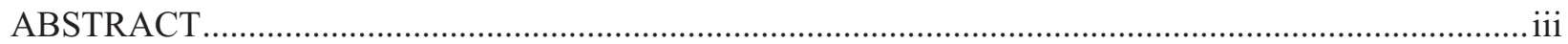

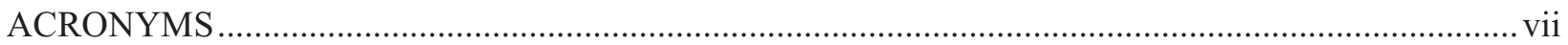

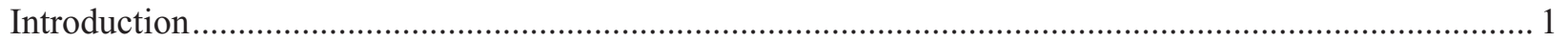

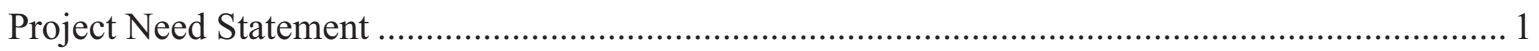

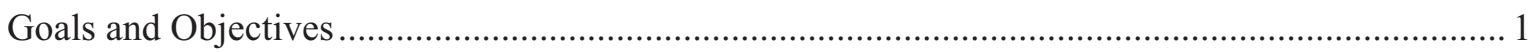

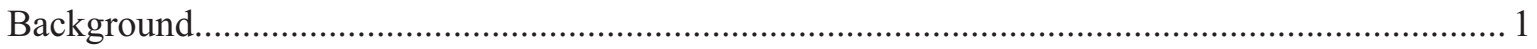

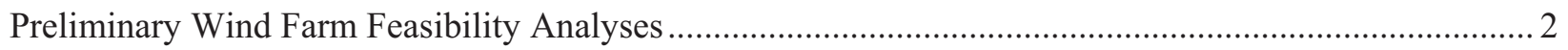

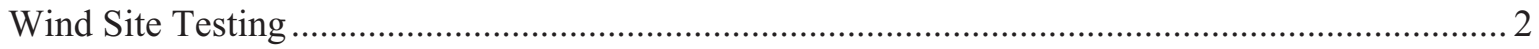

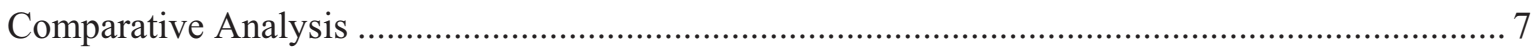

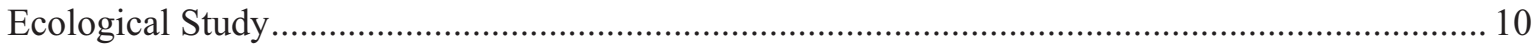

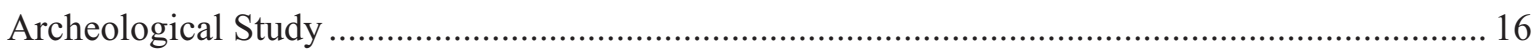

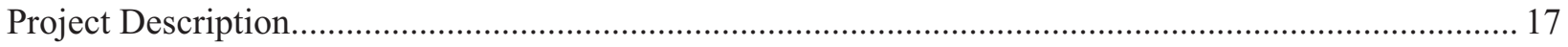

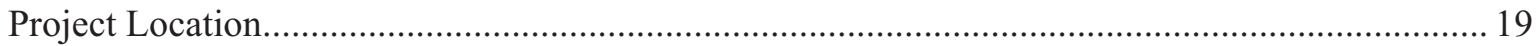

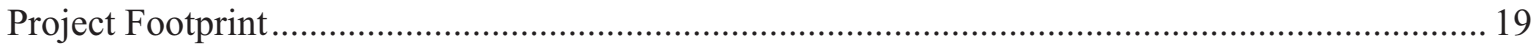

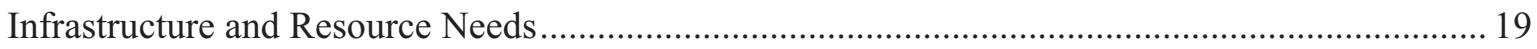

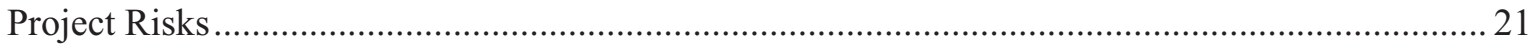

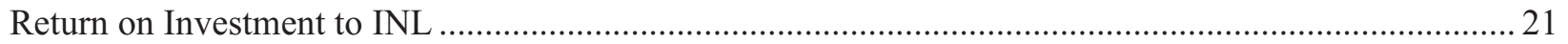

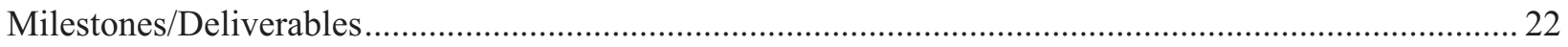

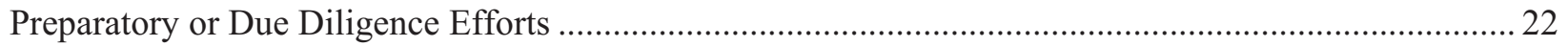

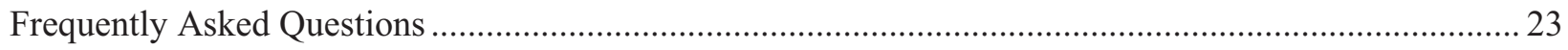

\section{FIGURES}

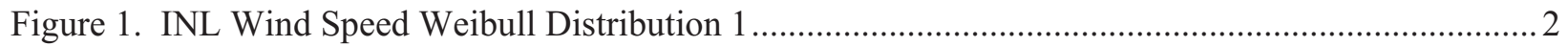

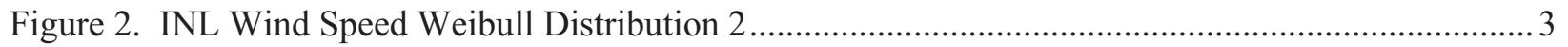

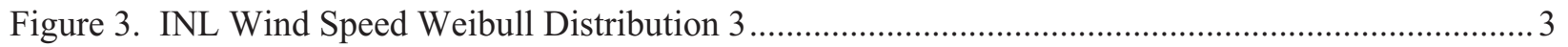

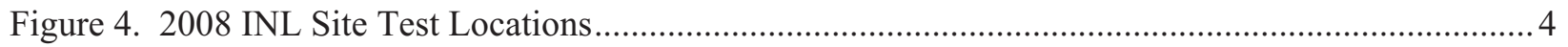

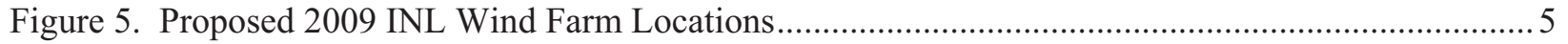

Figure 6. Closer Details of Potential INL Wind Turbine Locations (see red cloud areas) ........................ 6

Figure 7. Wind Farm Comparison to Other GPP Projects.................................................................... 8

Figure 8. Wind Farm Compared to Other GPCE Projects .................................................................... 9

Figure 9. Wind Farm Compared to Other LICP Projects...................................................................... 9

Figure 10. Generic GPS location of INL wind farm turbines (20 MW) ............................................20

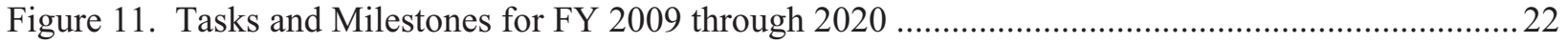


This page intentionally left blank. 


\section{ACRONYMS}

\begin{tabular}{ll} 
BEA & Battelle Energy Alliance \\
CFA & Central Facilities Area \\
DOE & Department of Energy \\
\multicolumn{1}{c}{-ID } & Idaho Operations Office \\
EA & Environmental Assessment \\
EC & Environmental Checklist \\
EERE & Energy Efficiency and Renewable Energy \\
EIS & Environmental Impact Statement \\
GPCE & General Purpose Capital Equipment \\
GPP & General Plant Project \\
IFM & INL Facility Management \\
INL & Idaho National Laboratory \\
LICP & Line Item Construction Project \\
MFC & Materials and Fuels Complex \\
MW & megawatt \\
NEPA & National Environmental Policy Act \\
NREL & National Renewable Energy Laboratory \\
PMO & Project Management Office \\
PREPS & Proposal Risk Evaluation and Preparation System \\
RCG & Reduced-cost Green Credits \\
RFI & Request for Information \\
RFP & Request for Proposal \\
ROI & Return on Investment \\
RPM & revolutions per minute \\
TEAM & Transformational Energy Action Management \\
UAV & Unmanned Aerial Vehicle \\
&
\end{tabular}


This page intentionally left blank. 


\title{
INL Wind Farm Project Description Document
}

\author{
Introduction
}

\section{Project Need Statement}

All government laboratories and agencies are mandated by Executive Order 13423, Strengthening Federal Environmental, Energy, and Transportation Management, to reduce their carbon footprint and to explore deploying alternate energy power generating solutions. As such, the Idaho National Laboratory (INL) needs to take an active role in the Western Renewable Energy Zone program and show leadership in achieving more energy independence for the country. Additionally, having a 20+ MW power plant onsite to complement INL test beds gives INL researchers another valuable resource for solving smart grid and integration issues.

This installation will show that the Department of Energy (DOE)/INL practices pollution prevention, uses renewable energy, reduces greenhouse gases, and also provides a test bed for researchers to solve energy and grid systems problems/issues.

\section{Goals and Objectives}

The overall goal of the INL wind farm project is, by 2010, to install a 20+ MW wind farm on INL lands that is funded and operated by a private third-party entity. Specific objectives of the project are as follows:

- Define the INL locations of the potential turbine sites to maximize wind resources.

- Prepare a full electrical instrumentation study.

- Complete all necessary NEPA and environmental documentation to permit the construction of a $20 \mathrm{MW}$ to $40 \mathrm{MW}$ wind farm and transmission line on INL lands.

- Purchase the hardware and install the transmission line between the wind farm site and the existing substation.

- Contract with a third-party developer/operator to fund, build, and operate the 20-40 MW wind farm on INL lands.

\section{Background}

On August 6, 2007, then Energy Secretary Bodman stated, "My specific requirements for the TEAM [Transformational Energy Action Management] Initiative are as follows ... Maximize installation of secure, on-site renewable energy projects at all DOE sites." Subsequently, the Office of Energy Efficiency and Renewable Energy (EERE ) tasked all DOE laboratories to assess their resources and identify potential renewable energy opportunities at their respective sites. The National Renewable Energy Laboratory (NREL) performed the preliminary screening, and the INL was on the short list of DOE sites with renewable energy assets. The most obvious alternative energy system at the INL is wind power because of the strong prevailing winds. James Wade of the DOE Idaho Operations Office (-ID) was asked to support this project, and Gary Seifert was assigned the technical management aspects. 


\section{Preliminary Wind Farm Feasibility Analyses}

\section{Wind Site Testing}

In early 2008, a several plans were developed to meet the Secretary of Energy's charter to assess INL Lands for potential wind power resources. The initial assessment process was submitted through both the Proposal Risk Evaluation and Preparation System (PREPS) and the INL Environmental Checklist (EC) systems. The title of the project was "Feasibility study to develop INL high wind sites for potential installation of full scale wind turbine/towers" (PREPS Project No. 0208-C.B-10-000546). This preliminary effort was required to assess wind resources on INL lands. At that time, discussions were held with interested site program personnel (i.e., Unmanned Aerial Vehicle [UAV] and Test Bed programs) and the site manager, Steve Winn, to explore the possibility of conducting feasibility tests in select areas of interest. The areas of interest were screened and permitted by the environmental staff to ensure the testing could be conducted at the locations. Additionally, site security was contacted and advised of every entry onto the INL system of dirt trails.

The tests consisted of small wind towers and a trailer-mounted Sonic Detection And Ranging (Sodar) system. The Sodar system is a meteorological instrument, also known as a wind profiler, which measures the scattering of sound waves by atmospheric turbulence. Analysis of the prevailing winds during 2008 defined and characterized several wind resource locations within the INL boundaries. The wind farm resource data captured during those tests is shown in Figure 1 through Figure 3. Figure 4 shows where the initial feasibility tests were conducted. Ultimately, the project successfully identified a location on INL lands with commercially viable wind resources (i.e., greater than $13.5 \mathrm{mph}$ annual average wind speed at 50 meters above ground level) for a 20 to $40 \mathrm{MW}$ wind farm. These commercially viable areas are shown in Figure 5 and Figure 6.
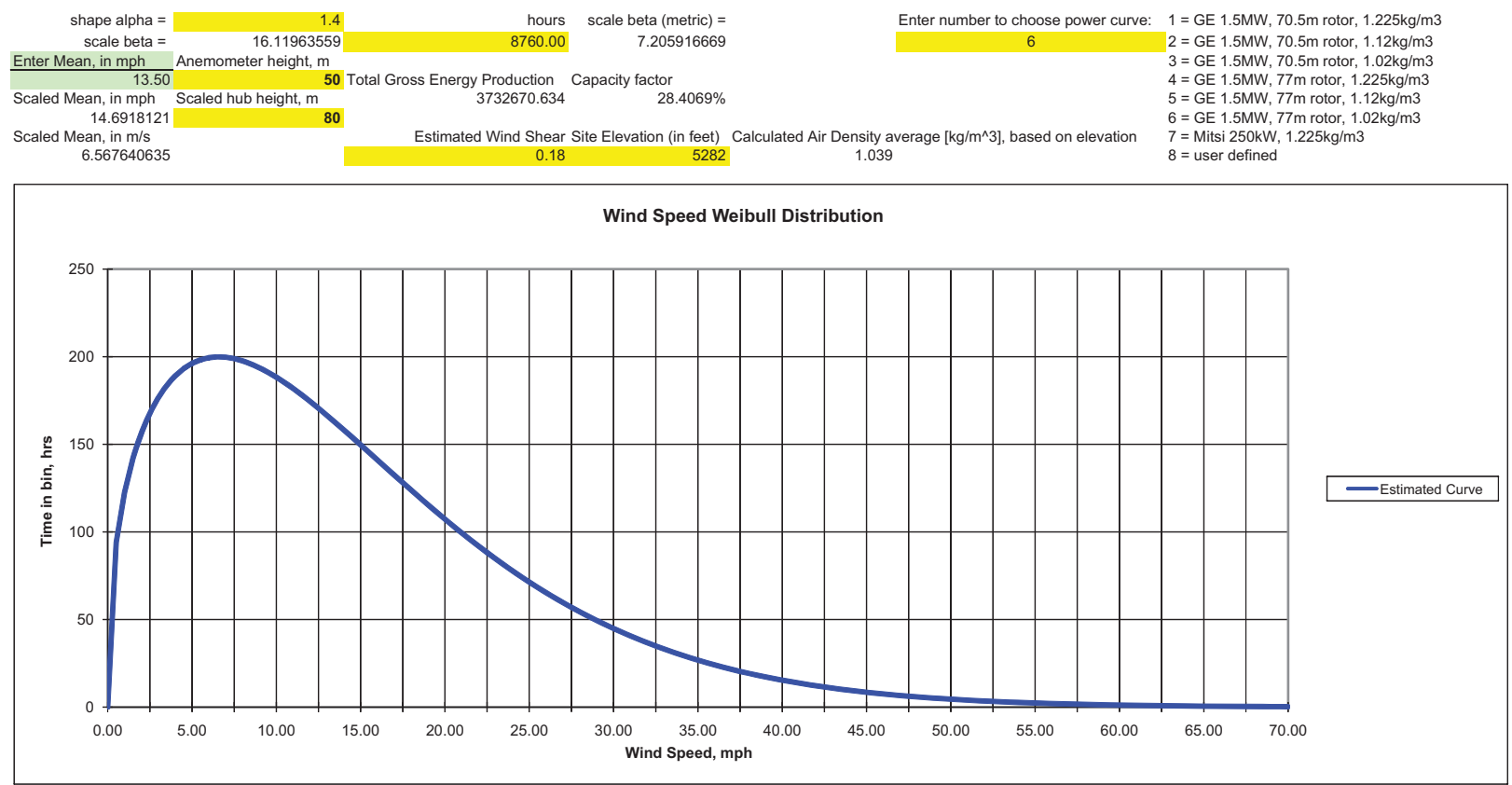

Figure 1. INL Wind Speed Weibull Distribution 1 


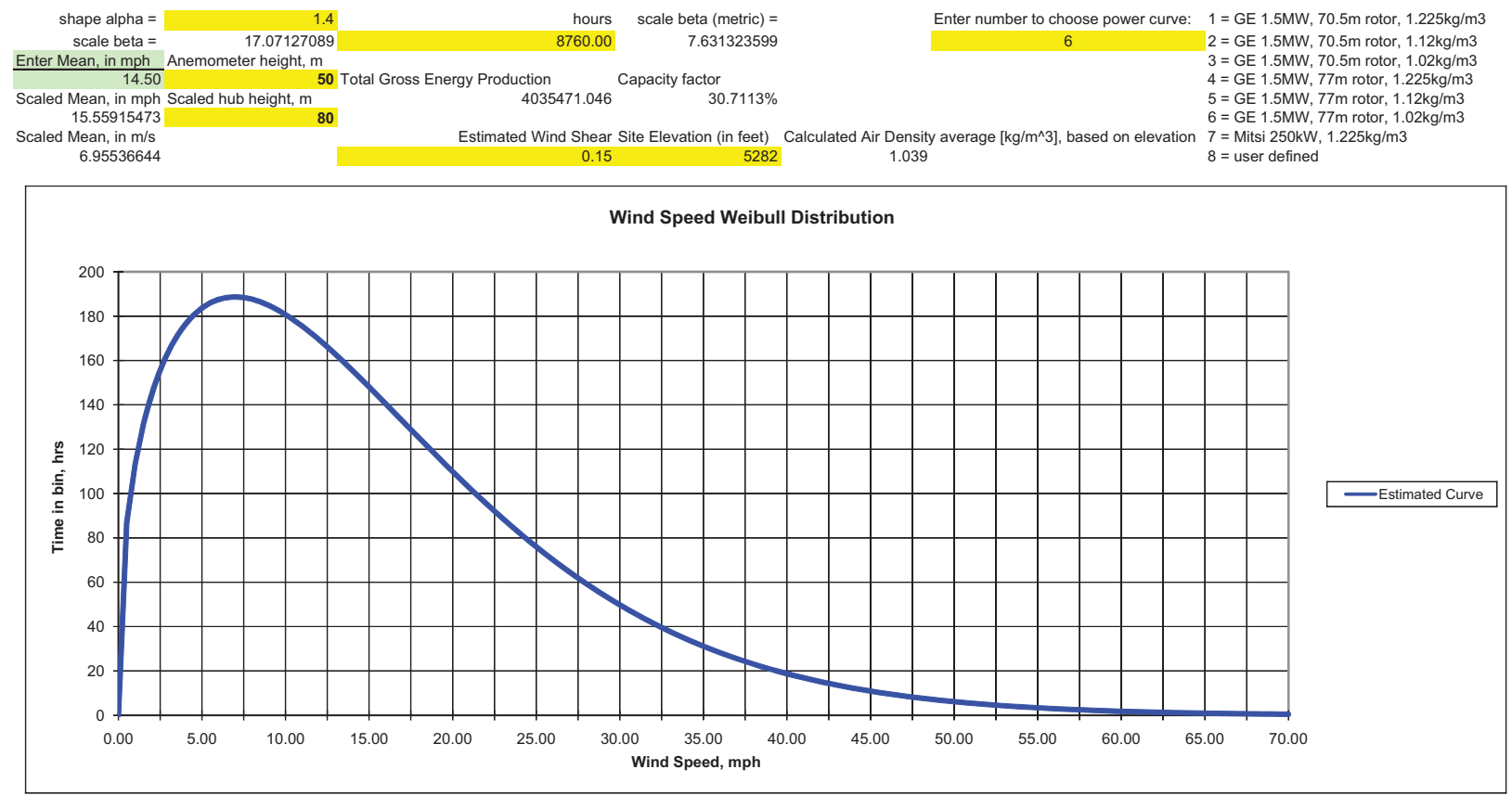

Figure 2. INL Wind Speed Weibull Distribution 2

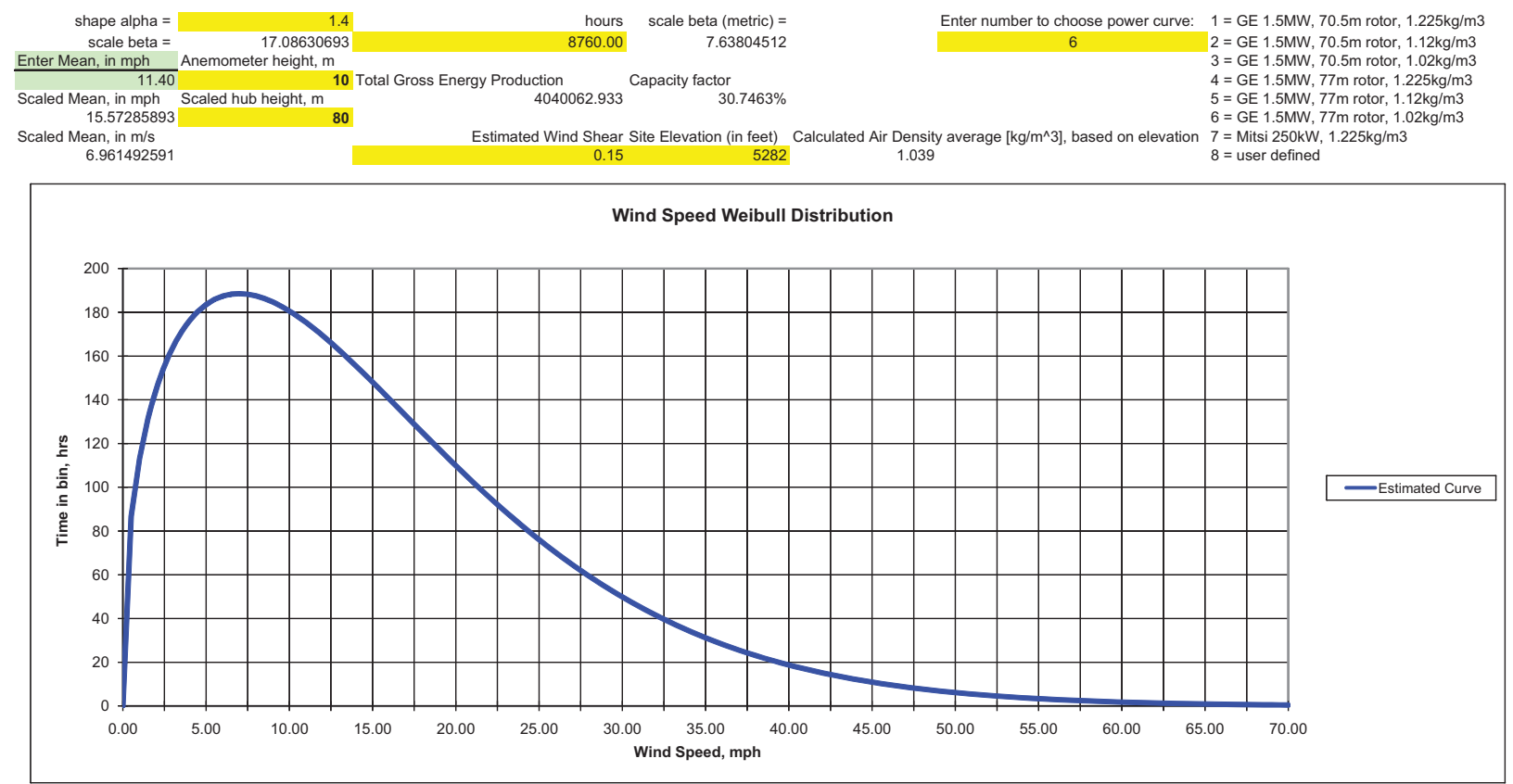

Figure 3. INL Wind Speed Weibull Distribution 3 


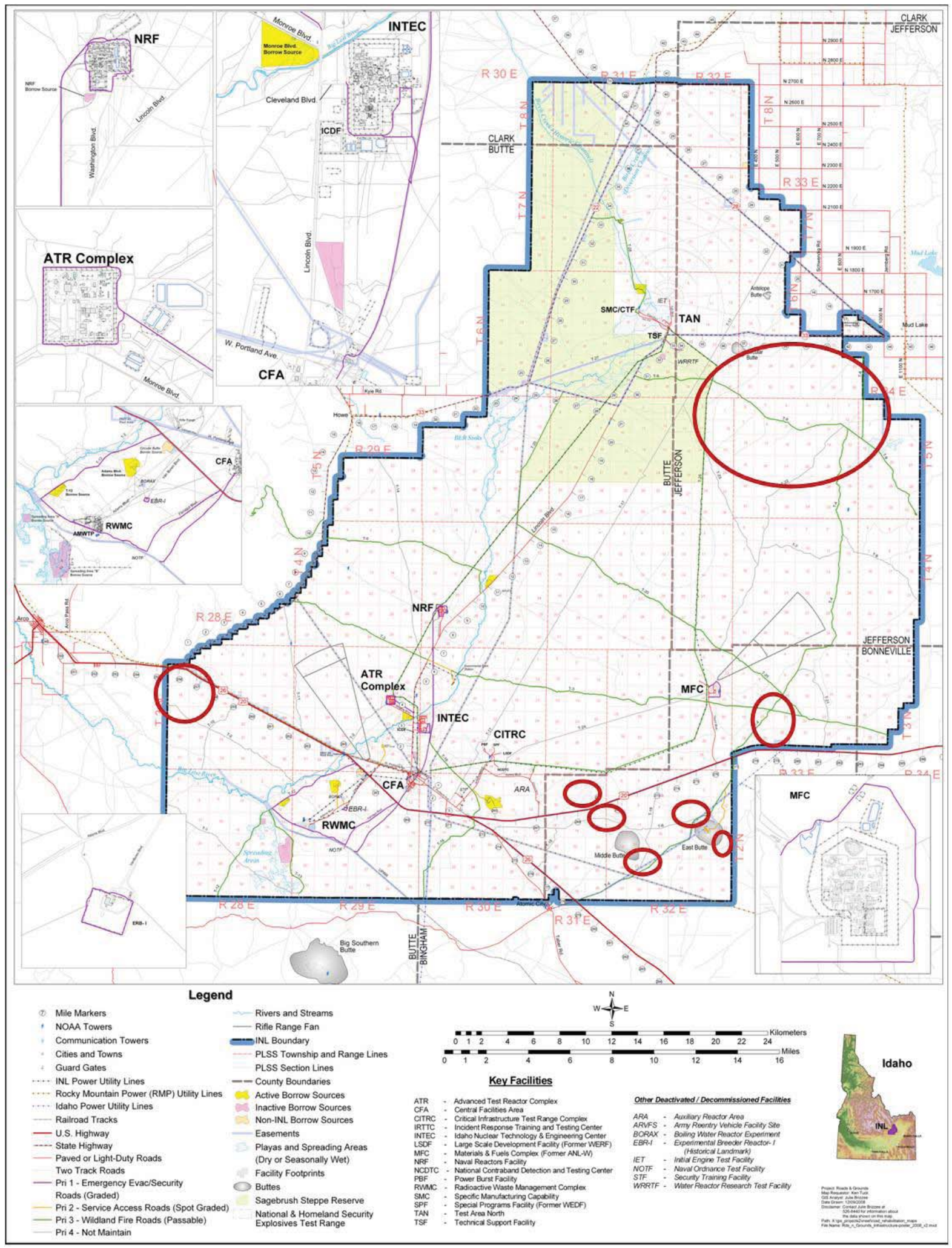

Figure 4. 2008 INL Site Test Locations 


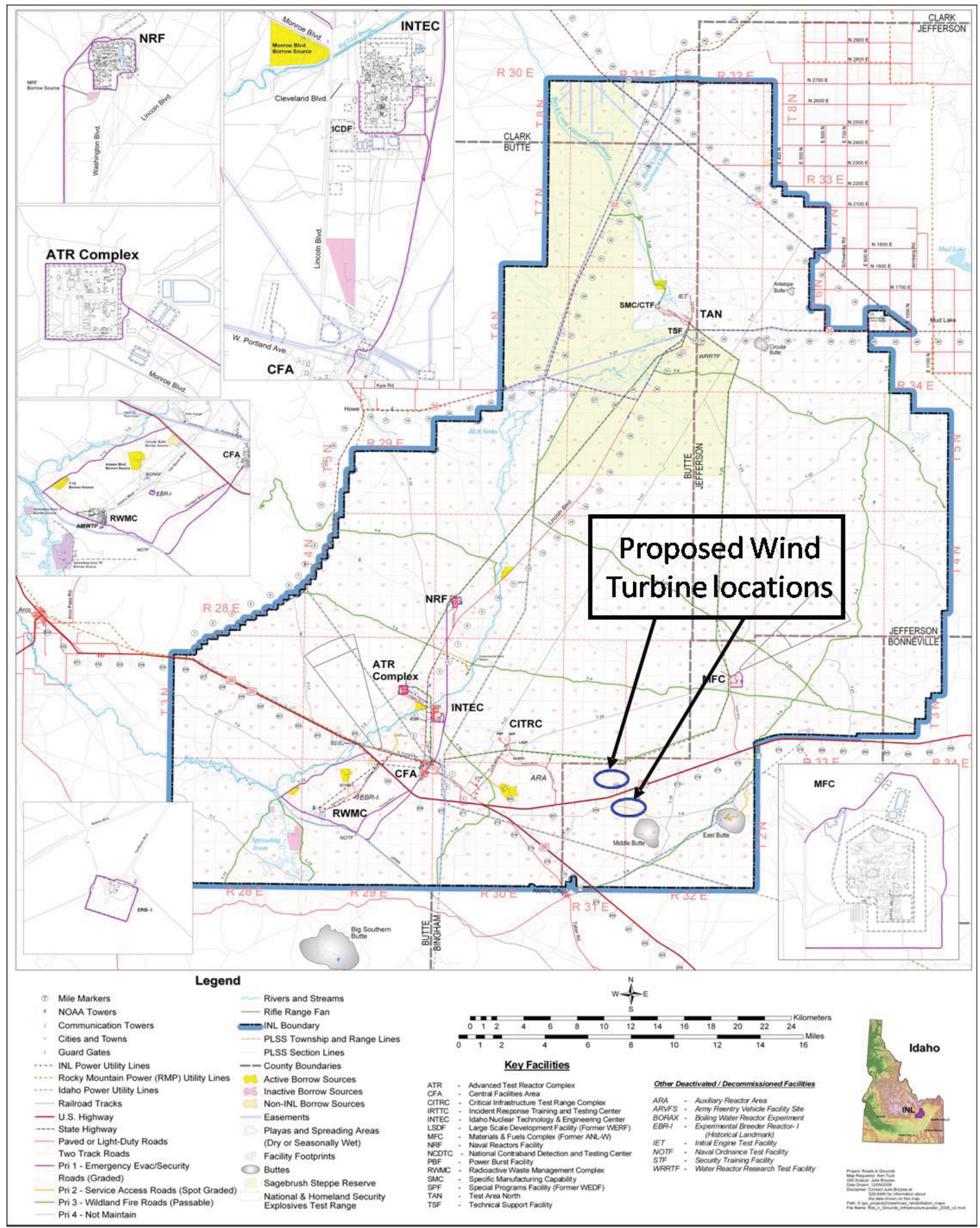

Figure 5. Proposed 2009 INL Wind Farm Locations 


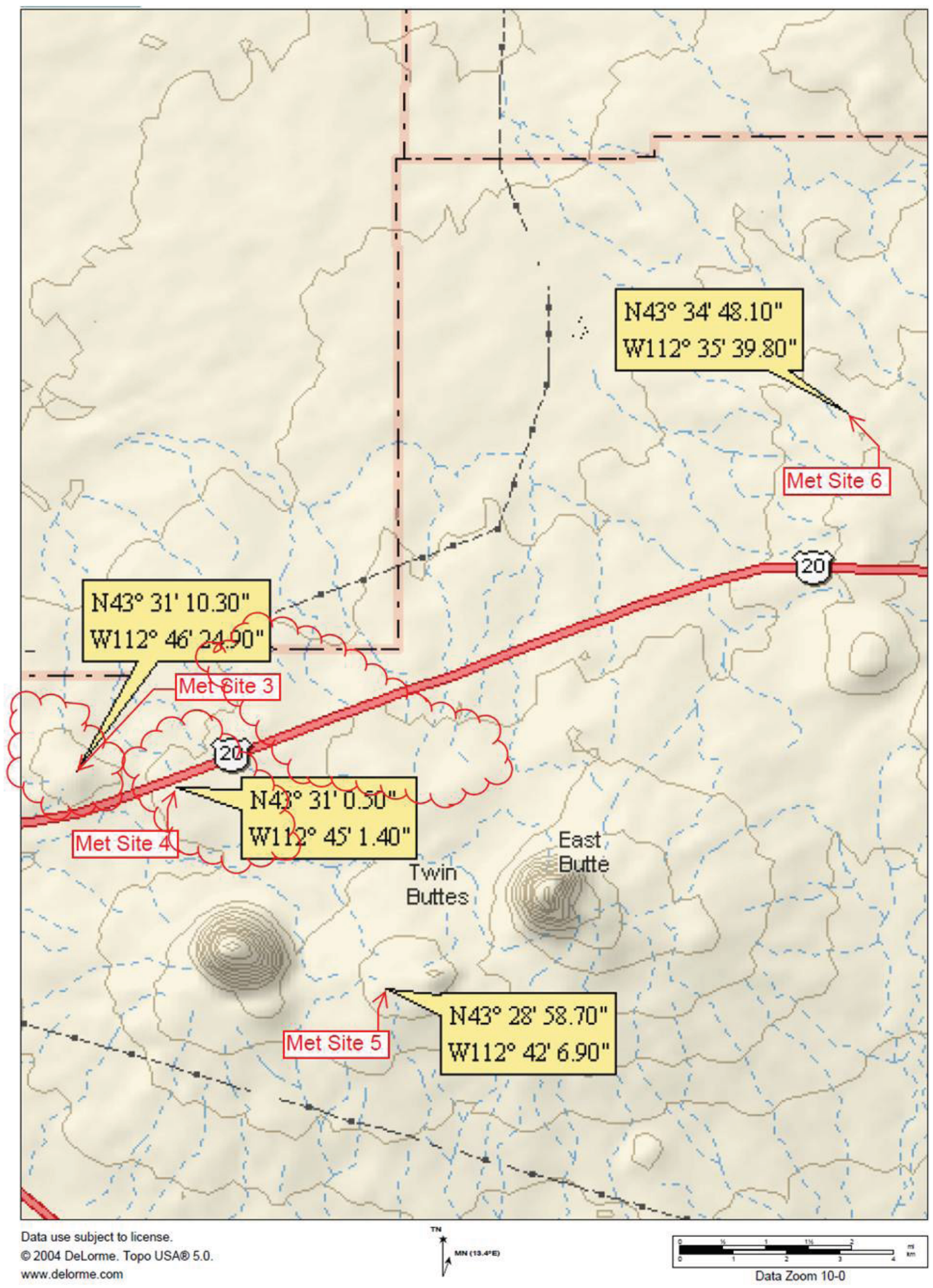

Figure 6. Closer Details of Potential INL Wind Turbine Locations (see red cloud areas) 


\section{Comparative Analysis}

Beginning in October 2008, the INL Systems Engineering Department assisted the Project Management Office (PMO) in developing a decision support capability to evaluate and rank General Plant Project (GPP), General Purpose Capital Equipment (GPCE), and Line Item Construction Project (LICP) funding requests. The tool is based on 13 criteria ( 7 derived from the INL Strategic Plan and 6 addressing risk), specifically tailored to support INL Facility Management (IFM) funding decisions.

At the request of the PMO, the Systems Engineering Department evaluated the proposed wind farm against other GPP, GPCE and LICP projects at the INL to show the relative importance of the proposed wind farm project. In making this comparison, it should be noted that of 13 criteria, only $60-65 \%$ are directly applicable to evaluating the wind farm because of the different funding and project goals involved. As such, results of the evaluation represent an "apples to oranges" comparison between the wind farm and all the other projects.

Figure 7 shows that the wind farm ranks $12^{\text {th }}$ out of 80 GPPs, or within the top $15 \%$. The comparison between the wind farm and the GPPs gives the best overall estimate of the relative importance of this project as compared to other projects at the INL. Figure 8 shows that the wind farm ranks $3^{\text {rd }}$ out of 34 GPCE projects, or within the top 10\%. The comparison between the wind farm and the GPCEs is the biggest stretch of the three comparisons included here. Figure 9 shows that the wind farm ranks $3^{\text {rd }}$ out of 5 LICPs, or right at the $50 \%$ mark. The comparison between the wind farm and the LICPs is the most realistic because of the kind of effort and overall funding needed. However, recent history and attitude about LICPs at the INL is such that few believe such projects will be funded; as such, only the most critical needs of this type are ever submitted. The subsequent indication is that the wind farm only ranks at the 50\% point among the most critical LICPs at the INL. In summary, the PMO assessment supports the proposed wind farm project as highly viable, and it aligns with the INL strategic plan. 


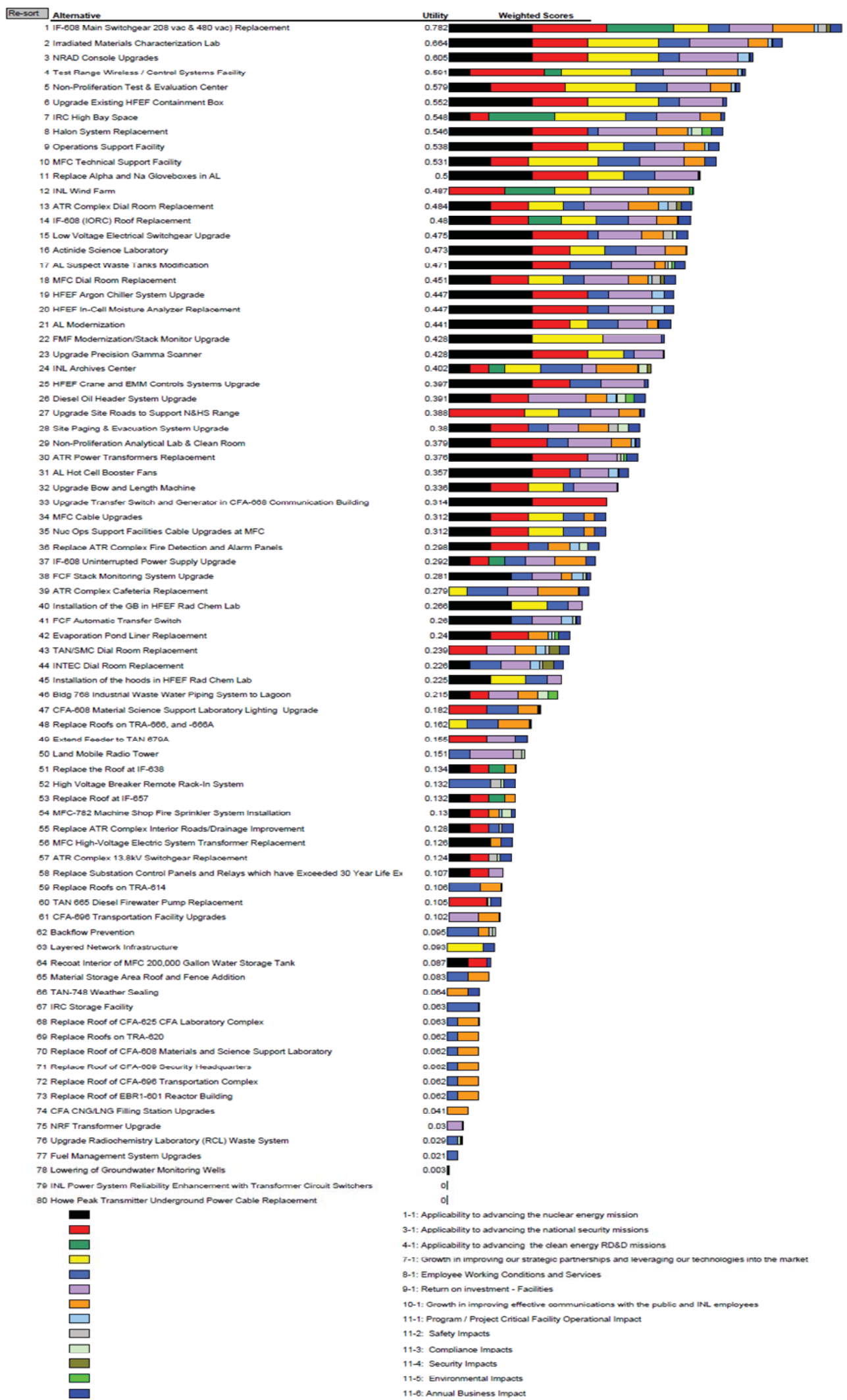

Figure 7. Wind Farm Comparison to Other GPP Projects. 


\begin{tabular}{|c|c|c|}
\hline \multirow{2}{*}{\multicolumn{2}{|c|}{ Re-sort Alternative }} & Weighted Scores \\
\hline & & 11 \\
\hline \multicolumn{2}{|r|}{2 Mechdyne FLEX Immersive Display System } & 0.56 \\
\hline \multicolumn{2}{|r|}{3 INL Wind Farm } & 0.487 \\
\hline \multicolumn{2}{|r|}{4 Powerwall } & 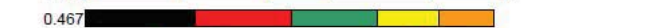 \\
\hline \multicolumn{2}{|r|}{5 in Vivo Whole Body Count System } & $1 \quad \| \square$ \\
\hline \multicolumn{2}{|r|}{6 TLD Dosimetry Reader } & 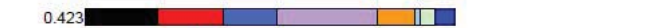 \\
\hline \multicolumn{2}{|r|}{7 HDW Heat Exchanger Equipment } & ב \\
\hline \multicolumn{2}{|r|}{8 CFA and EROB Dial Room (INET) UPS Expansion } & 11 \\
\hline \multicolumn{2}{|r|}{9 Network service capacity upgrade } & 1 \\
\hline \multicolumn{2}{|r|}{10 Taylor 25 ton lift truck } & 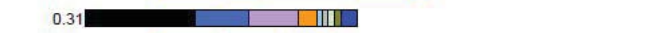 \\
\hline \multicolumn{2}{|r|}{11 Ambulance (3 units) } & 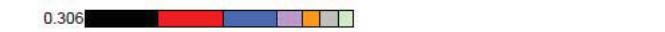 \\
\hline \multicolumn{2}{|r|}{12400 GPM Liquid Flow Calibrator Dedicated to Water } & 0.291 \\
\hline \multicolumn{2}{|r|}{13 Voice Mail end-of-life system replacement } & $0.286 \square$ \\
\hline \multicolumn{2}{|r|}{14 Hydraulic Press Brake } & 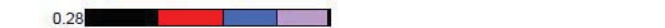 \\
\hline \multicolumn{2}{|r|}{15 Radiation Detection Equipment for Sitewide Environmental Monitoring } & 1110 \\
\hline \multicolumn{2}{|r|}{16 Century Sterilizer/Amsco Steam Generator } & I \\
\hline \multicolumn{2}{|r|}{17 Mazak Quick Tum CNC Lathe } & 0.222 \\
\hline \multicolumn{2}{|r|}{18 HAAS CNC Turning Center } & 0.222 \\
\hline \multicolumn{2}{|r|}{19 Disk Storage Hardware } & 0.221 \\
\hline \multicolumn{2}{|r|}{20 Laser Etcher } & 0.172 \\
\hline \multicolumn{2}{|r|}{21 Sodick Wire EDM Machine } & 0.164 \\
\hline \multicolumn{2}{|r|}{22 Computer Controled Plasma Table Cutting System } & 0.164 \\
\hline \multicolumn{2}{|r|}{23 Replace INL Paging System } & $0.162 \square$ \\
\hline \multicolumn{2}{|r|}{24 HAAS V5/50 Mill } & 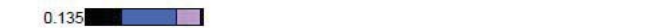 \\
\hline & 2515,500 pound-rated long tine, outdoor, diesel, all terrain fork-lift with a cab & $0.091 \square$ \\
\hline & 26 Dump Master (Garbage Truck) & $0.086 \square \square$ \\
\hline & 27150 GPM Liquid Flow Calibrator (Dedicated to simulated fuel oil) & 0.063 \\
\hline & 28 INL Enterprise Geographic Information System & 이 \\
\hline & 29 X-Ray Imaging System & 이 \\
\hline & 30 Enterprise Computing Infrastructure Servers & ol \\
\hline & 31 Enterprise Network Switch Replacement & 이 \\
\hline & 32 HPC Computing Platforms & ol \\
\hline & 33 HPC Network Transport & ol \\
\hline & 34 Enterprise Storage Area Network & 이 \\
\hline & ש & 1-1: Applicability to advancing the nuclear energy mission \\
\hline & $\square$ & 3-1: Applicability to advancing the national security missions \\
\hline & $\square$ & 4-1: Applicability to advancing the clean energy RD\&D missions \\
\hline & $\square$ & 7-1: Growth in improving our strategic partnerships and leveraging our technologies into the \\
\hline & $\square$ & 8-1: Employee Working Conditions and Services \\
\hline & $\square$ & 9-1: Return on investment - Equipment \\
\hline & $\square$ & 10-1: Growth in improving effective communications with the public and INL employees \\
\hline & $\square$ & 11-1: Program / Project Critical Facility Operational Impact \\
\hline & $\square$ & 11-2: Safety Impacts \\
\hline & $\square$ & 11-3: Compliance Impacts \\
\hline & $\square$ & 11-4: Security Impacts \\
\hline & $\square$ & 11-5: Environmental Impacts \\
\hline & $\square$ & 11-6: Annual Business Impact \\
\hline
\end{tabular}

Figure 8. Wind Farm Compared to Other GPCE Projects

Re-sort Alternative
1 ATRC Control System Upgrade
2 INL. Enterprise Computing Data Center
3 INL Wind Farm
4 Building-Specific Network Switch and Cable Upgrades (IORC, EROB, WCB)
5 Probabilistic Seismic Hazard Analysis

Figure 9. Wind Farm Compared to Other LICP Projects. 


\section{Ecological Study}

At the request of the wind farm project, the S. M. Stoller Corporation conducted a preliminary review of ecological resources that may be impacted by the proposed wind farm. The following letter report identifies the presence of sage grouse and pygmy rabbits as the primary issues of concern and recommends further studies as the project moves forward, but offers no show stoppers.
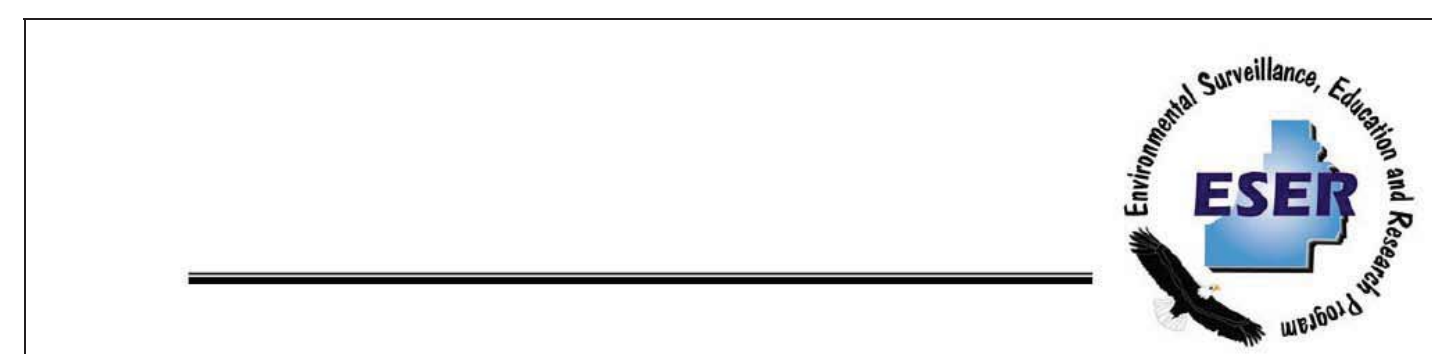

June 1. 2009

Mr. Gary Seifert

Idaho National Laboratory

P.O. Box 1625

Idaho Falls, ID 83415

Subject: Preliminary Ecological Review of Proposed INL Wind Farm Locations.

Dear Mr. Seifert:

The Wind Powering America Project has made a proposal to install a 20MW wind farm on the INL Site by 2010. An ecological review of the areas proposed for the Project is necessary. This letter report provides background information on ecological resources potentially in the vicinity of four alternative locations on the INL Site for the wind farm. The surveys reported here are not intended to serve as a comprehensive inventory of ecological resources, but rather to identify those resources present that may require additional consideration by the Project and additional ecological review as the Project moves forward.

Primary issues of concern for these areas would be the presence of sage-grouse and pygmy rabbit. These two species are presently under consideration for protection under the Endangered Species Act (ESA). A finding for sage-grouse is expected by the end of June. The pygmy rabbit finding was expected in January, but has yet to be released. Additional consideration for these two species would likely be necessary for any of the proposed locations. However, as noted below, field surveys did not find evidence for these two species at some of the proposed sites.

Our first task was to review existing data on ecological resources of concern, primarily focusing on sagegrouse and pygmy rabbit, in the general vicinity of the proposed wind farm on the INL. We are presently conducting surveys for these two species on the INL. For sage-grouse this includes a radio-telemetry study to identify areas and habitat types being used for nesting, brood rearing and wintering habitat. Locations of sage-grouse with radio transmitters are included on Map 1. It is important in interpreting these maps to recognize that these locations are only for those sage-grouse with radio transmitters. Other sage-grouse undoubtedly use similar habitat nearby, but are note depicted.

Also depicted on Map 1 are sage-grouse breeding areas, known as leks. Protecting habitat for non-migratory populations when sagebrush is distributed uniformly includes minimizing disturbance to sagebrush and herbaceous understory within $3.2 \mathrm{~km}$ from active lek locations, and $5 \mathrm{~km}$ when sagebrush is not distributed uniformly. The map depicts these buffer areas around known leks.

Current results of pygmy rabbit surveys are also noted on Map 1. Pygmy rabbit surveys have not been conducted on the entire area depicted on the map. These surveys are conducted at random points to determine the presence or absence of pygmy rabbit burrows. It is important in interpreting this map to understand that the pygmy rabbit burrow locations are representative of only those points that have been surveyed and is not a complete census of burrow locations within the project area. Other pygmy rabbit burrows are likely to be present, but are not depicted.

The S. M. Stoller Corporation 120 Technology Drive • Idaho Falls, ID 83401

Phone: 208-525-9358 • Fax: 208-525-3364 • wwW.stoller-eser.com 
We conducted brief walking surveys of four areas proposed for the project. The areas and proposed turbine locations are noted in Maps 2,3 and 4. Results of the surveys are summarized below.

Area 1 (Hwy 20 to T-25, north of Middle Butte)

We surveyed this area on May 19. No signs of pygmy rabbits were documented. We saw sage-grouse tracks between towers 2 and 3 , and we saw sage grouse scat between towers 2 and 3 and 7 and 8 . Tower 1 is located in a sagebrush shrubland with some cheatgrass present. Towers 2 and 3 are located within a rabbitbrush shrubland community that has very little diversity and few invasive species. Towers 4 and 5 are within the burned area that is scoured clean and mostly devoid of vegetation. Towers 6 and 7 are still within the burn but there is good native and/or crested wheatgrass cover. Towers 8,9 , and 10 are located in a very diverse, native, sagebrush steppe shrubland area. Relatively few weeds exist in this area and those that are present are non-native annuals such as cheatgrass and halgeton.

\section{Area 2 (east of Area 1, between Hwy 20 and T-25)}

We surveyed this area on May 20. No signs of pygmy rabbits were documented. We saw sage grouse feces between towers 2 and 3 . Tower 8 is located in a burned community that is dominated by crested wheatgrass. Tower 9 is located in a sagebrush shrubland with a crested wheatgrass understory. Tower 1 is surrounded by rabbitbrush shrubland located within a burn. Towers 2 and 3 are located in a sagebrush shrubland with a native understory. The area surrounding towers 4,6 , and 7 are dominated by rabbitbrush and bluebunch wheatgrass and are within the burn. There are some scattered areas of cheatgrass. Tower 5 is located on a mound of disturbed soil that is dominated by halogeton. The area is surrounded by the rabbitbrush/bluebunch wheatgrass community mentioned above. From a vegetative ecological standpoint, this would be the preferred location for the wind farm.

\section{Middle Butte Area}

We surveyed this area on May 20. No signs of pygmy rabbits or sage grouse were documented. This entire area is located within an old burn. The vegetation community is rabbitbrush/bluebunch wheatgrass shrubland with a diverse compliment of other native perennial species. There is some presence of crested wheatgrass, cheatgrass, and halogeton but it is sparse and patchy across the landscape.

\section{East Butte Area}

We surveyed this area on May 19. No signs of pygmy rabbits or sage grouse were documented. Tower 2 is located in a burned juniper area that is recovering well with native species. Tower 3 is in a bluebunch wheatgrass/threetip sagebrush recovery area. Tower 4 is a juniper area that burned very hot and scorched the soil resulting in extensive areas of bare ground. Tower 1 is surrounded by sagebrush shrubland. This area is generally very unique and has a diverse range of species not often seen across the INL. The number of weeds is low in this area.

If you have any questions about the surveys, the existing data, or any of the information in this report, do not hesitate to contact any of us.

Sincerely,

Roger D. Blew, Ph.D.

S.M. Stoller

120 Technology Dr.

Idaho Falls, ID 83401

cc: Larry Zirker BEA

ESER Files
Jackie R. Hafla

Jericho Whiting, Ph.D. 


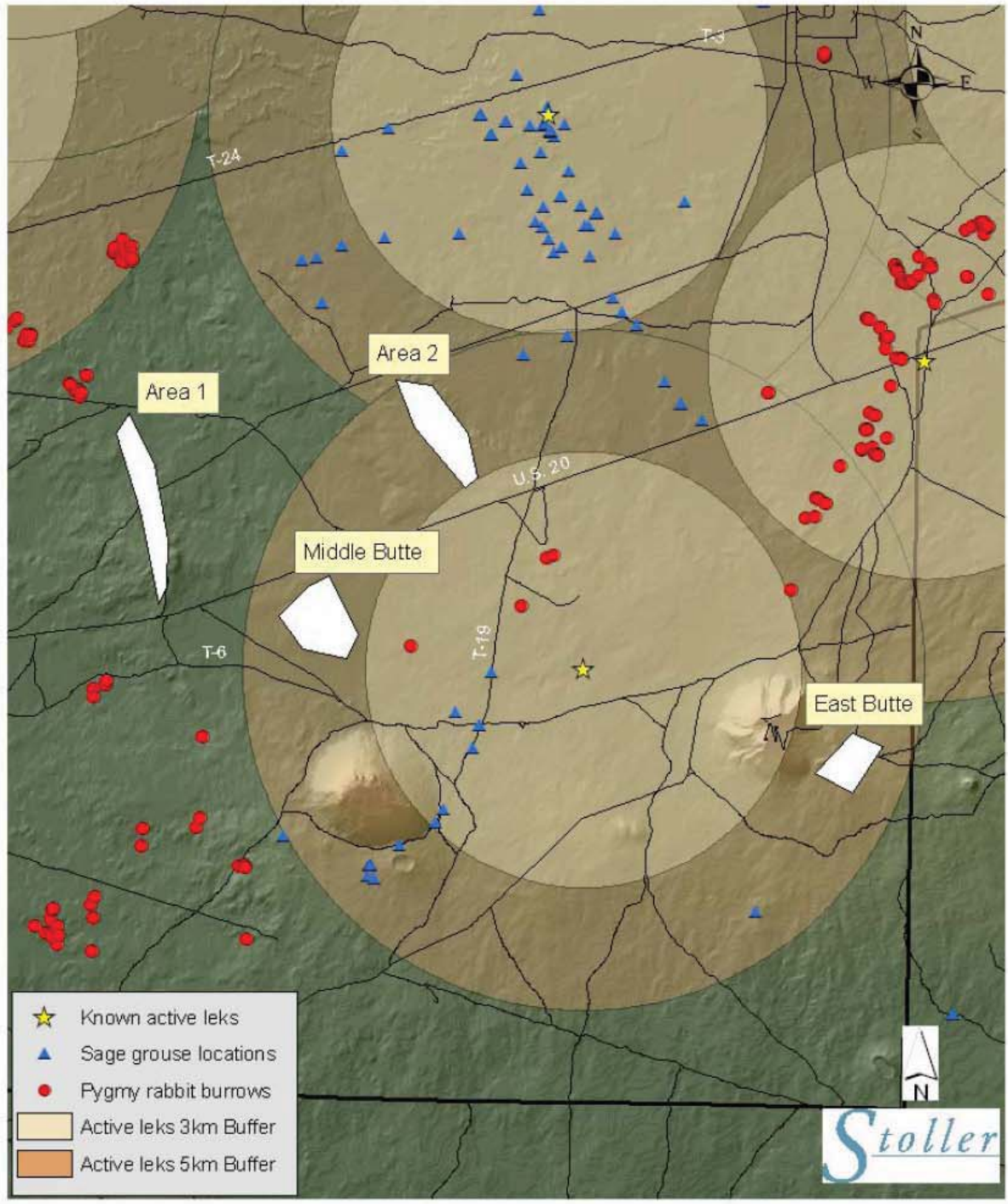

Map 1. Existing survey data for sage-grouse and pygmy rabbit in the vicinity of the proposed project. 


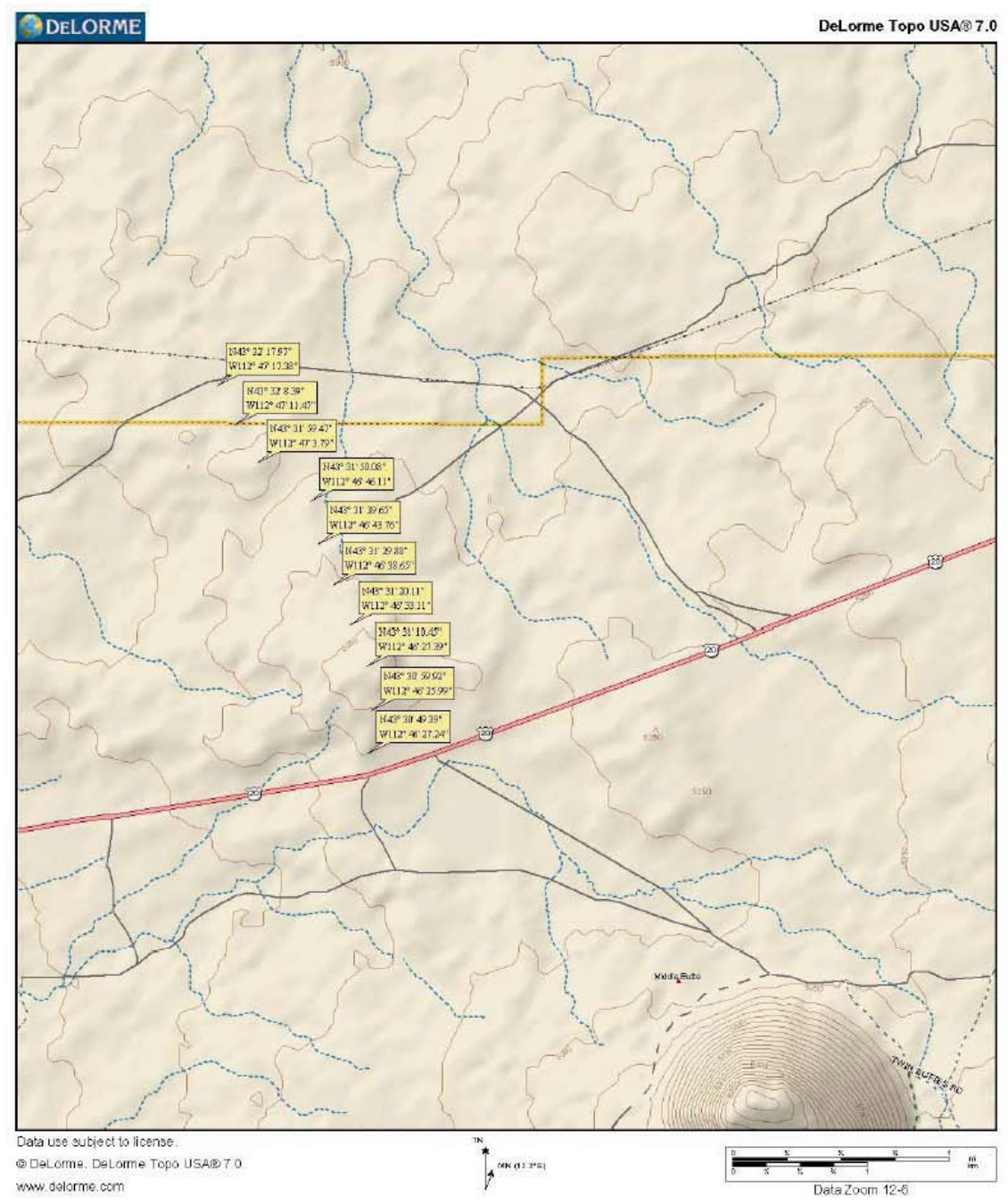

Map 2. Area 1 proposed turbine locations. 


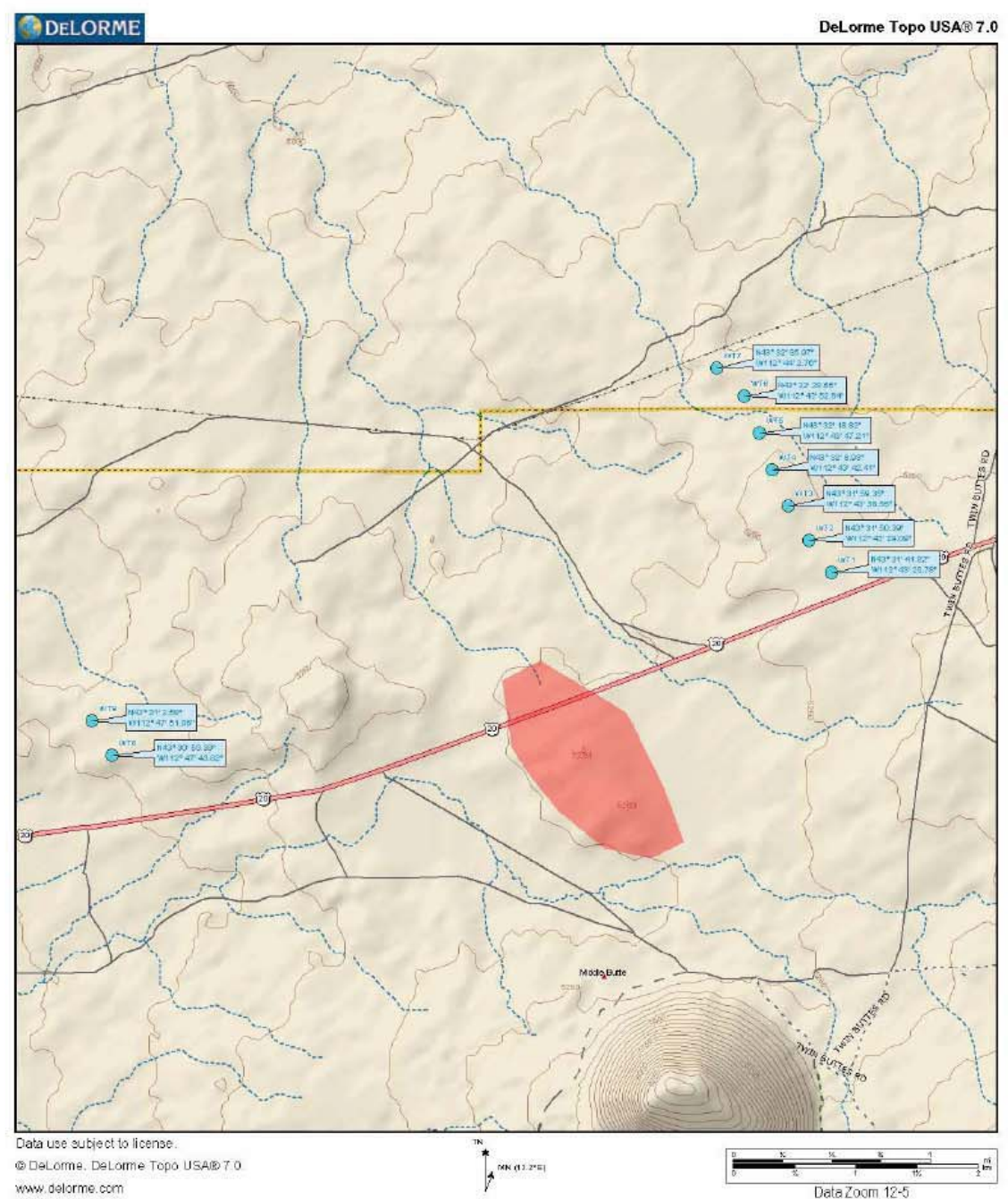

Map 3. Area 2 proposed turbine locations and Middle Butte Area (red polygon). 


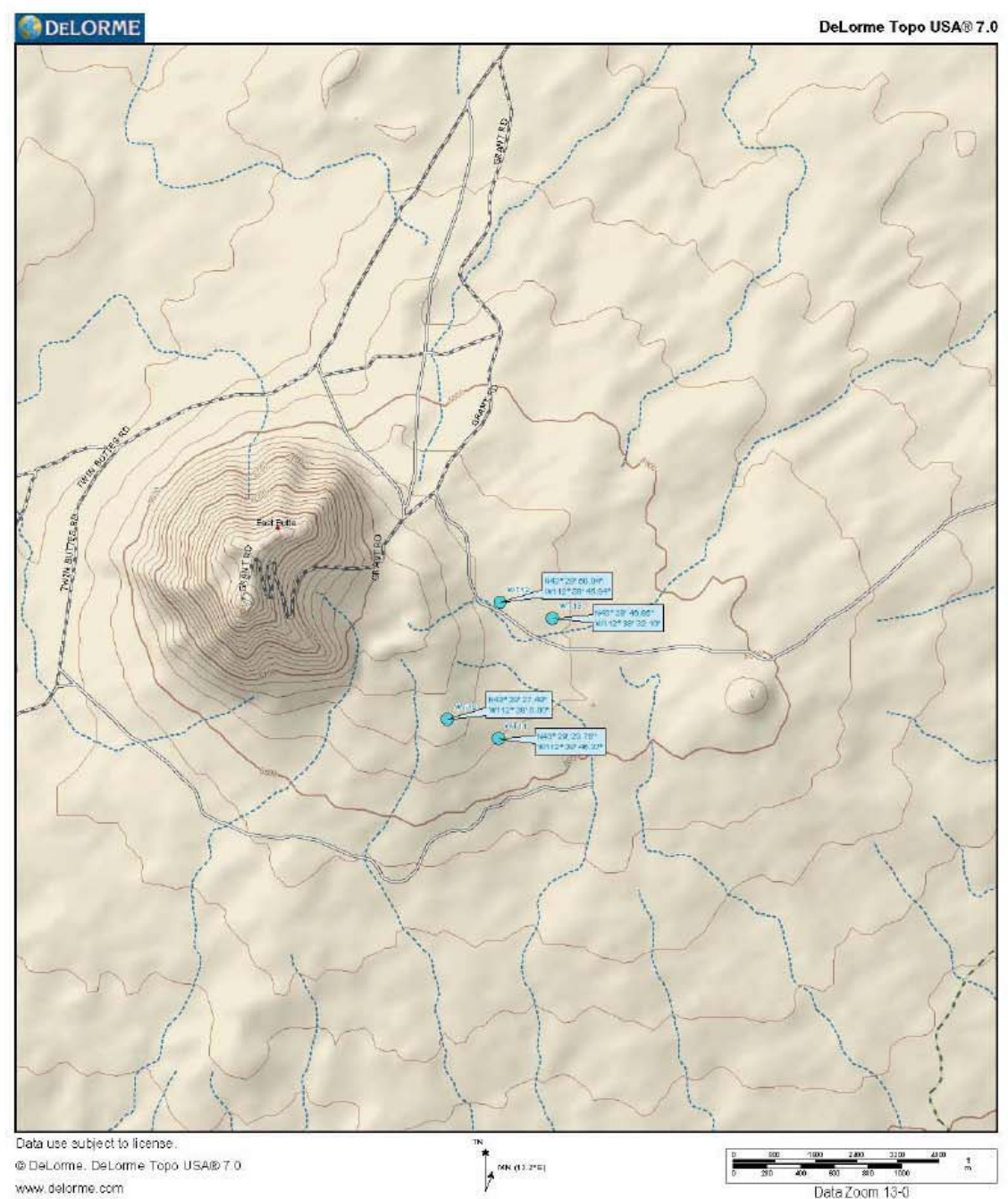

Map 4. East Butte proposed turbine locations. 


\section{Archeological Study}

Archeologists at the INL conducted a study of the 160 meter-wide corridor currently identified as the prime location for the proposed wind farm. The following email correspondence identifies the likely archeological impact due to the high density of archeological materials in the proposed locations, offers mitigation methods, and identifies no show stoppers.

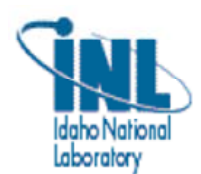

Brenda R

Pace/BXR/CC01/INEEL/US

05/29/2009 12:46 PM

\author{
To Gary D Seifert/SEI/CC01/INEEL/US@INEL \\ cc Kurt S Myers/MYERKS/CC01/INEEL/US@INEL, Larry \\ Zirker/ZIRKLR/CC01/INEEL/US@INEL, Julie B \\ Braun/JLI/CC01/INEEL/US@INEL, John A \\ Koudelka/KOUDJA/CC01/INEEL/US@INEL \\ Subject Cultural Resource Survey Preliminary Results
}

Hi Gary, we have completed an archaeological survey of a 160 meter-wide corridor centered on the line of proposed wind towers extending north of Hwy 20 out to the $135 \mathrm{kV}$ power line. As you can see from the attached map, the density of archaeological materials in this area is very high. As a result, I believe it will be challenging to avoid impacts if this area is chosen for construction. Not impossible, but challenging to be sure.

As we've discussed informally, it may be possible to avoid some impacts through slight adjustments in tower, road, and trench locations. By surveying the 160 meter-wide corridor, we have obtained information for areas that may be suitable for this "micro-siting." However, I believe it is unlikely that all impacts can be avoided and that some archaeological mitigation through excavation will be necessary if the towers are built here. Continued interaction with the Shoshone-Bannock Tribes will also be a necessity. All of these activities are driven by federal law and DOE-ID agreements with the Tribes and the State of Idaho.

I'm not sure where we are in the NEPA process, but believe that you will probably need to have a report documenting the results of the survey and assessment of potential impacts to include/reference in the EA or EIS. If there are other locations under consideration for installation, they should also be subjected to some level of cultural resource survey and reported in the same technical document. I'm going to hold off on preparation of this report until hearing from you because I believe it will take approximately $60 \mathrm{hrs}$ to complete. In the interim, I'm providing the attached map for project planning and discussion, but please ensure that the information on archaeological site locations is kept in confidence and is not released to the public.

I'll be out of the Office next week (June 1-5), but will try to touch base with you on June 8 to clarify a path forward. If you have any questions about the map while I'm out, please contact John Koudelka (6-8591). Talk to you soon! --Brenda

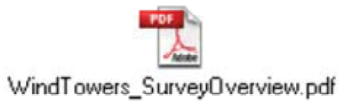

Brenda Ringe Pace

Registered Professional Archaeologist Idaho National Laboratory

P.O. Box 1625-2105

Idaho Falls, ID 83415

Office:(208) 526-0916

Cell: (208) 520-5458 


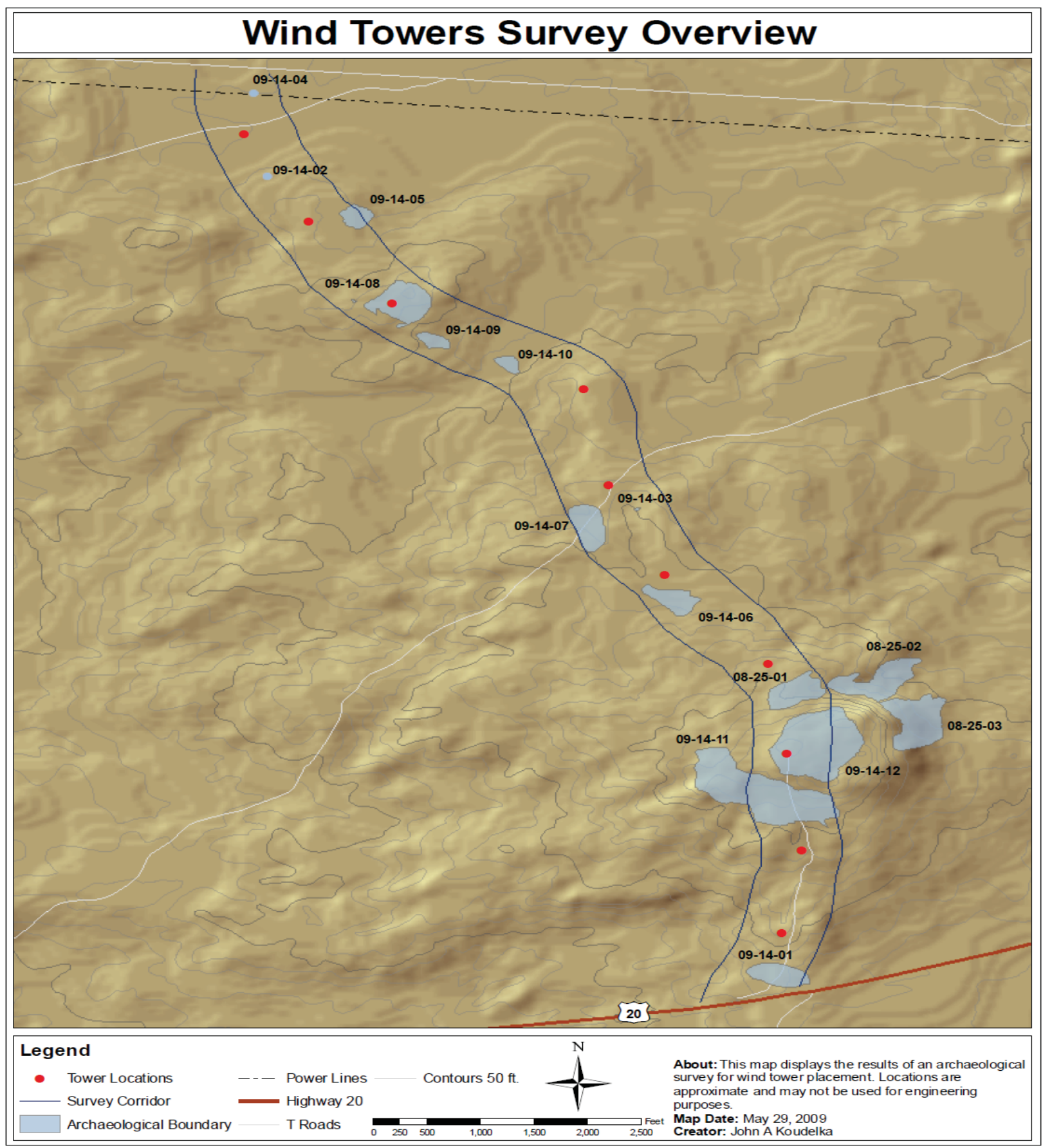

Note that the only areas of archaeological concern on the map are the blue shaded "archaeological boundaries." Ground disturbance within those blue shaded areas will impact archaeological/cultural resources, but those impacts can be mitigated or completely avoided by some combination of the following types of activities:

- slight relocations of the towers, roads, and other ground disturbances to areas that are not shaded blue

- additional data collection, probably including some archaeological excavation, in advance of ground disturbance to collect the important information/artifacts before disturbance 
- placement of fill over the top of sensitive areas to cap the cultural deposits and insulate them from disturbance

- archaeological monitoring of ground disturbance with authority to temporarily redirect work if any significant materials are encountered

With planning and work in advance of construction, these are not "show-stoppers." Outside the blue shaded areas, there are no archaeological concerns, so construction activities can proceed there without causing any impacts to archaeological resources. Additional surveys and micrositing will be developed to address these concerns.

\section{Project Description}

Based on the results of preliminary testing and analysis, the INL wind farm project proposes to install a $20 \mathrm{MW}$ to $40 \mathrm{MW}$ wind farm on government property, consisting of approximately ten to twenty fullsized (80-meter hub height) towers with $2 \mathrm{MW}$ turbines, and access roads. This includes identifying the optimal turbine locations, building access roads, and pouring the tower foundations in preparation for turbine installation. Third party financing, operations, and maintenance have been identified as the only viable alternative for placing the wind farm on INL lands. As such, the actual turbines would be built, owned, and operated by a private third-party under separate contract. The number and size of the turbines may change based on availability; typical turbine sizes range from 1.5 to $2.5 \mathrm{MW}$. The final layout will be determined by the sizes of turbines purchased for the project.

Once the turbines are in place, an INL transmission line will distribute the generated power. A nearby transmission line currently connects the Central Facilities Area (CFA) and the Materials and Fuels Complex (MFC). A short transmission line (a few hundred yards) will be required from the edge of the wind farm to the existing transmission line where it will route to MFC using the same or new poles and easement.

Due to the complexity and costs for a private third-party to build and operate a wind farm on government lands, the INL wind farm project proposes will:

1. Obtain permission from DOE and the Battelle Energy Alliance (BEA) Land Use Committee to pursue the project. This includes meeting with both committees to present the merits of the project and ascertain if the project meets the scope and mission of DOE and BEA. Permission from both committees is required to proceed with the project.

2. Obtain all permits, licenses, or approvals to construct the wind farm and install the transmission line on INL lands. Part of the approval will be given from the DOE and BEA land use committees. The next major review will be with the DOE NEPA Board that will review the project and determine what, if any, subsequent assessments will be required: specifically, an environmental assessment (EA) or an environmental impact statement (EIS). This review will define all of the required permits and documents for the project. Because of the complexity of citing a $20 \mathrm{MW}$ wind farm on the DOE lands and relatively small size, no commercial entity would assume the financial risk to obtain all of the permits, licenses, or approvals to construct the wind farm and install the transmission system. Therefore, the INL project team intends to prepare the environmental permits and governmental authorizations for a commercial wind farm to be constructed on DOE lands to foster competitive pricing for the power system and minimal impact.

3. Purchase hardware and install the transmission line on INL land (optional).

4. Issue the Request for Proposal (RFP) and allow the third-party builder and operator to build and operate the wind farm. This includes issuing a preliminary Request for Information 
(RFI) to gather industry input prior to preparing the final RFP to build and operate the INL wind farm. After industry comments have been addressed and reviewed by INL and DOEHeadquarters, a procurement strategy will be prepared. A RFP will then be issued and a contract awarded to a contractor.

5. Obtain the wind farm-specific permits. This includes the typical and customary due-diligence permits and documents required of a wind farm developer. A partial list would include soil analysis tests, aviary studies, Federal Aviation Administration reviews, general construction approval, Idaho Fish and Game reviews, INL mission review, interconnect studies, and power purchase agreements.

6. Make the electrical interconnection to the MFC substation. This includes designing the interconnection, purchasing the supplies, and installing the transmission line from the edge of the wind farm and into the MFC substation. The final connection will be made when the wind farm is energized. During final siting, alternate electrical connections will be evaluated.

7. Build and operate the INL wind farm. This entails building and operating the wind farm.

With preliminary permitting and infrastructure items in place, the overall financial risk is greatly reduced and this project becomes very attractive for a private third-party to fund, construct, and operate a wind farm on government lands. Contractual agreements will be determined as the project is permitted and matures.

\section{Project Location}

It is often asked why wind turbines have to be placed on ridges. The answer is simply because that is where the best wind resources are located. Since the energy available at a site is proportional to the cube of its speed, which means that doubling the wind speed increases the available energy by a factor of eight. Therefore it is essential to maximize the location of the towers in the best wind area to maximize the wind turbine's performance.

As noted above, several locations within the boundaries of the INL were assessed to evaluate the wind values. Most locations were found to not have adequate wind resources (see Figure 4). Commercial wind projects typically require at least a Class 3 resource. A Class 3 wind resource typically has annual average wind speeds of between 6.4 and 7.0 meters per second (14.3-15.7 miles per hour) at 50 meters above ground level. From all of the locations tested or evaluated on the INL, three specific areas north of the middle butte were found to have adequate Class 3 wind resources (see Figure 6). The best locations are shown in Figure 10. Other locations are currently under analysis for other potential wind farms.

\section{Project Footprint}

Proposed turbines will be located about 1100-feet apart and based on using Siemens 2.3 MW turbines. The actual disturbed soil would be less than 15 acres and include the tower pads and the access roads. These turbine locations may be adjusted slightly, to maximize exploitation of the wind. Additionally, the wind farm will use the existing transmission line and roads along the north edge of the wind farm to the extent practical, as shown in Figure 10.

\section{Infrastructure and Resource Needs}

Infrastructure and resourced needs to install and operate the INL wind farm include:

- A $60 \mathrm{~Hz}$ distribution power line from the INL electric system to enable power generation from and operation and control of the individual turbines. 
- An interconnection point on the electrical system to distribute generated power to the INL grid. Actual generation will typically be less than $10 \mathrm{MW}$, with peaks approaching $20 \mathrm{MW}$.

- Use of the easement (and preferably under build) for the electrical service between the wind farm and the MFC substation or other substations.

- A staging area and maintenance support building.

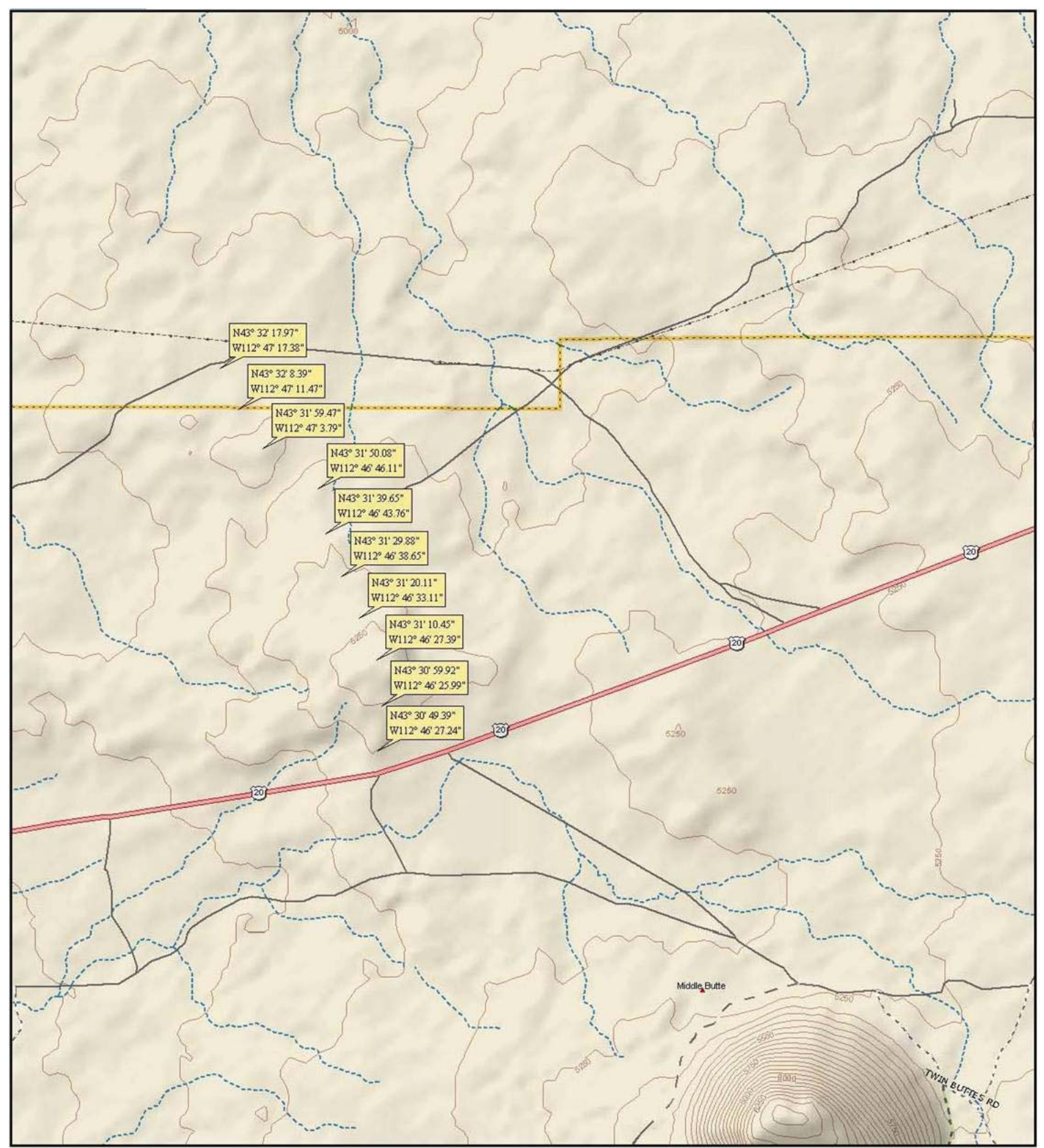

Figure 10. Generic GPS location of INL wind farm turbines (20 MW) 


\section{Project Risks}

The largest perceived risk is "view-shed" issue with local stake holders. As such, turbines will be painted off-white to significantly reduce the visual impact. Other risks include potential interference with historical Native American Tribe artifacts and with endangered species, both plant and animal. There is also potential risk of injury during the installation and operation of the wind farm. All of these can be mitigated. The removal of the towers and reclaiming the roads at the end of life shall be the responsibility of developer/operator. This reclamation shall be detailed in the land use agreement.

\section{Return on Investment to INL}

The return on investment (ROI) to the INL is threefold: a financial payment, meeting alternative energy mandates, and work for others opportunities. Typically, a lease payment is made to landowners from the project developers. This payment can come in a variety of methods: a monthly payment, a profit sharing from the wind generated power, reduced-cost green credits (RGCs), a reduction of costs for power, or a hybrid of these and other methods. This methodology will be determined as part of the RFI/RFP process.

"Green credits" resulting from the installation of the INL wind farm can be used to meet federal mandates and milestones regarding use of green power. As a result, the public will become more aware and accepting of DOE and INL efforts to practice pollution prevention and use alternative energy. Additional benefits to the INL are as follows:

- No financial obligation to the INL or the DOE beyond site preparation

- No radiological or hazardous waste issues

- No water needs beyond those required during construction (dust suppression and concrete)

- No need for sewer, snow removal, or security services.

The proposed wind farm and associated substation enhances work for others efforts at the INL by providing the resources and infrastructure necessary to conduct critical testing with wind industry partners. Further, adding a wind-generated power source to the INL test bed adds a dimension to the power, security, and smart grid tests heretofore not available. 


\section{Milestones/Deliverables}

The project tasks and milestones are shown in Figure 11.

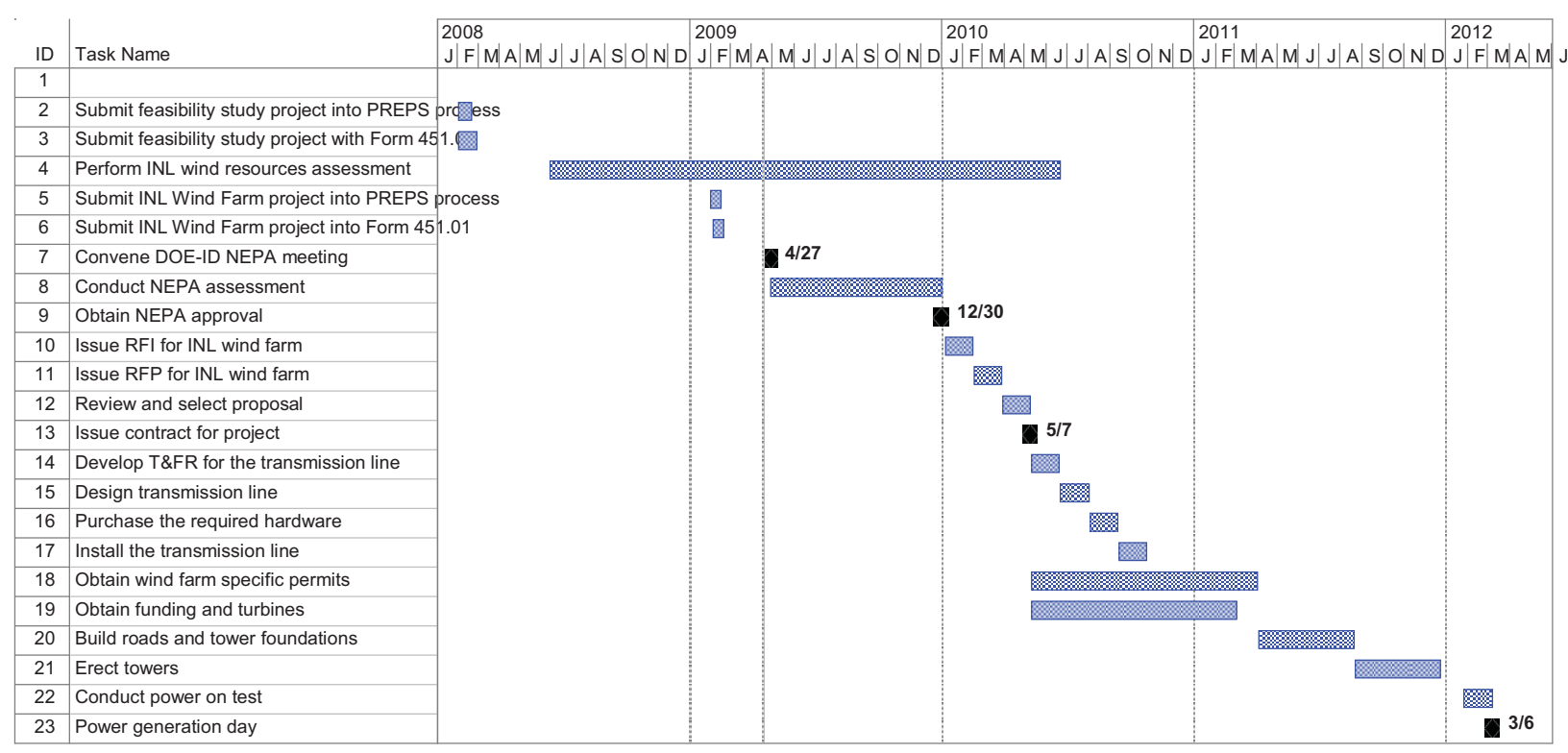

Figure 11. Tasks and Milestones for FY 2009 through 2020

\section{Preparatory or Due Diligence Efforts}

The following preparatory or due diligence efforts have already been completed:

- On February 8, 2008, the initial wind resource assessment project, Feasibility Study to Develop INL High Wind Sites for Potential Installation of a Full Scale Wing Turbine/Towers, began by putting the project into the PREPS system.

- On March 6, 2008, the project team submitted an INL Form 451.01, Environmental Checklist, so the project could conduct a feasibility study to assess the wind resources on the INL lands.

- On February 4, 2009, the INL wind farm project was submitted for approval through the PREPS process.

- On February 12, 2009, the INL wind farm project submitted an INL Form 451.01, Environmental Checklist for the wind project.

- On April 21, 2009, a morning walk-down at the wind farm site will be conducted with INL and Native American teams to determine what, if any, "view-shed" issues exist. Concurrent with this walk-down, a subsequent assessment will be conducted to assess the endangered species issues of the locations.

- On April 21, 2009, a meeting held with the INL/BEA Land Use Board to discussed project related issues. They made suggestions and this document reflects their input.

- On April 27, 2009, the DOE NEPA Board and DOE Land Use Board meeting was held to review the project. They had some concerns, many questions answered, but they requested 
that they receive a letter from John Grossenbacher that the INL wind farm project had his blessing.

- In May, an independent walk-around by Stoller Environmental and INL's archaeology team provided high-level reviews of the biological and cultural issues relating to three areas near the middle butte where the wind resources are located.

\section{Frequently Asked Questions}

Several questions have already been asked related to the INL wind farm. These include:

1. Will the 10-20 MW of energy cause safety problems to the other INL facilities when the grid goes down?

ANSWER: When the grid goes down, the controls at the wind facility shut down the wind turbines. This is a industry standard failsafe condition and meets national safety standards.

2. With the blades on the 10 towers kill birds?

ANSWER: Some birds are killed on most wind farms, but the number is typically less than a handful every year. The turbine blades on the proposed turbines are slow ( 15 RPM) as compared to the fast blades on smaller turbines that have the reputation of being bird killers. The project will perform an avian study and then implement best practices resulting in very low mortality rates. INL's avian population is at low risk.

3. Will the towers affect wild life?

ANSWER: The turbines are automatic and are operated from remote locations; therefore, human interference is minimal once construction is complete. Elk and deer have been known to bed-down in the shade of the towers and history shows that they tend to return to normal patterns after construction is complete.

4. Will the turbines impact power quality or INL mission?

ANSWER: All turbines operate in compliance with grid standards and do not impact other uses of the power line. Also, power system analysis studies are performed during the interconnect study to validate and confirm compatibility.

5. What can be done to minimize view shed concerns?

ANSWER: The location will take advantage of normal view blockage by the Buttes and will make use of an off white paint scheme to significantly reduce visual impact. 